\title{
Oral Communication Needs of Pre-Service Teachers in Practice Teaching \\ DOI: https://doi.org/10.47175/rielsj.v1i1.31
}

\author{
${ }^{1}$ Cebu Technological \\ University, Cebu City, \\ Philippines \\ ${ }^{2}$ Palawan State University, \\ Rizal Campus \\ ${ }^{1}$ cristieann.ph@gmail.com \\ 2afpressk12@gmail.com
}

| Cristie Ann L. Jaca ${ }^{1}$ | Felino B. Javines ${ }^{2}$ |

\begin{abstract}
Practice teaching is the culmination of the teacher education program where student teachers apply learned content knowledge and pedagogical skills in real classroom teaching. The purpose of this paper is to present the perceived oral communication needs of student teachers during their practice teaching. Survey questionnaire, classroom observations and focused group discussions were used to collect the needed data. It was found that student teachers' oral communication skills in English fall short and need to be enhanced to cope with the demands of the teaching profession. Likewise, it was noted that the need to have a special kind of English class for pre-service teachers is very much needed to help them in their practice teaching since the medium of instruction used in class is English. Furthermore, the kind of English they need for classroom communication is also very specific for classroom interactions. The findings serve as basis in designing a module that can be used in remedial class in English for Pre-Service Teachers to respond to their communicative needs in the classroom.

KEYWORDS

Language needs; oral communication ability; practice teaching; pre-service teachers; student-teachers
\end{abstract}

\section{INTRODUCTION}

Good oral communication skills are pre-requisites of effective teaching (Delfin, 2009) for they are the teacher's means of building rapport with students thus fulfills a number of discipline-specific pedagogical functions (Rahman, 2010). As such, language has become an essential component in the delivery of instruction. As such, teachers model communication to students (Betty, 2009) that is why they are expected to be fluent in the medium of instruction they use in the classroom (Aldo, 2010). The Pre-service teachers' communications skills are challenged when they have they practice teaching since they do have enough competence and confidence in speaking in English during their classroom teaching.

Quality pre-service teacher education is a key factor in ensuring quality education in the Philippines (RA 7722, Article 1, Section 1). Hence, it is of utmost importance that Teacher Education Institutions must produce teachers who not only have the knowledge, skills, attitudes and values in teaching but also have the needed communication skills in English for it is the medium of instruction used in Secondary schools. The Enhanced Basic Education Act of 2013 poses a challenge to Teacher Education Institutions to improve the quality of teacher education programs in order to produce professional teachers who can facilitate positive learning outcomes among students. The government rationalized this educational reform as an enhancement of the basic education curriculum to improve the quality of learning outcomes to meet international accreditation standards. 
The Student Teaching Program is governed by CMO No.11 s. 1999 which specifies the Policies and Standards for Teacher Education. It focuses on the "preparation of globally competitive teachers who are imbued with the Christian ideals, aspirations and traditions of Philippine life and are sufficiently equipped with pedagogical knowledge and skills." During the Student Teaching part of Pre-Service teaching, future teachers get to experience the reality of classroom teaching as they are assigned to handle classes with the help of a teaching mentor.

However, the most observable challenge that student teachers encounter is their communication skills as these are pre-requisite to their classroom teaching. Despite the two Communication Arts classes and one Speech class that the student teachers enrolled in their first two years in college, their language ability during classroom discussions is still limited and they fall short of the oral communication skills expected of them as future teachers (Delfin, 2009). Pre-service teachers are expected to have good oral communication skills in English for this the medium of instruction used in their teaching. Thus, they are expected to develop their language skills so they can deliver their lessons smoothly and process students answers with fluency in the language. Part of Chan's (2001) study on university students' view of their language needs identified problems that constrained their learning of English, including thinking in L1, the lack of opportunity to speak English, and their lack of confidence when speaking English. As such training in speech communication is necessary (Hunt, Simonds, Cooper, 2010) to provide enough opportunities for pre-service teachers to hone their communication skills before their teaching practice. This study presents the perceptions of the pre-service teachers of their oral communication ability during their practice teaching vis a vis the classroom observation conducted to determine how they fare in their language ability in their respective classrooms.

\section{Statement of the Problem}

This study aimed to determine and analyze the oral communication needs of pre-service teachers during their practice teaching experience. Specifically, this study sought to answer the following questions: What are the language skills and oral communication skills needed by the student teachers in their practice teaching? What are the suggested activities to improve their English language proficiency? What challenges in oral communication do they encounter in their classroom teaching? How may an English language training/program be designed in order to address these needs? The findings serve as basis in designing a remedial class in English for Pre-Service teachers.

\section{Literature Review}

The role of the 21 st century teacher is increasingly seen as involving the ability to work in a team and collaborate with colleagues and also to work within an institution taking on different roles and responsibilities where necessary (Darling-Hammond, 2006; Freeman et al., 2009; Leung, 2009). Thus, effective communication skills are a critical component of teaching. If there is a mismatch between what is conveyed and what was intended to be conveyed, then even the best teaching decisions can bring out ineffective teaching outcomes (Low, E., Chong, S., \& Ellis, M. (2014). Communicative competence and language proficiency has been studied for years (Canale and Swain, 1980; Celce-Murcia, 2008; Richards; 2010). Canale and Swain (1980) explain communicative competence as the user's knowledge of syntax, morphology and phonology in relation to their appropriate use in meaningful utterances. Dunbar, Brooks, Kubicka-Miller (2006) explained that students need speaking and listening skills that will help them succeed in future courses and in the workplace. The importance of oral communication skills for teachers and future teachers cannot be underestimated (Bee, 12; McCarthy and Carter, 2001) as they are basic skills in 
every profession especially in teaching and learning. There are even studies that identified communication strategies used by pre-service English teachers that either facilitate or hinder the development of communicative skills (Garces and Olivera, 2013;) and the importance of providing speech communication training to pre-service teachers (Hunt, Simonds, Cooper, 2010).

Studies on pre-service teachers' language and communication skills competence (Kana, 2015; Vessallo, Kerri, \& Grech, 2017) though vary in scope and dimensions but emphasizes fluency and accuracy in language skills development. Ganal \& Andaya (2015) state that student teachers go through different problems in preparing themselves for teaching because they do not have any experiences teaching in the classroom before they were fielded to their cooperating schools.

Learning to be a teacher is a complex and very personal matter that involves transformation from "students of teaching" to "teachers of students" (Ganser, 2002). The professional life of a teacher is accompanied by a set of expectations such as professional behavior, the ability to communicate, team working, reflecting and learning (Denby, 2012). As such there is often a mismatch between theoretical methods and reality (Miller and Aldred, (2000). These are the challenges that teachers encounter in their teaching practice. Student-teachers experience during their practicum reflect the school and classroom complexity of place, ideology, knowledge, pedagogy and student-teacher assessment that lead them to question, modify, or abandon what they have learnt in their higher education initial teacher education courses in light of what often seems to be a different philosophy and practice (Russell, 2000; Sinclair, Munns, \& Woodward, 2005) as cited by Sinclair, 2007. Richards (2010) as cited in Low, E., Chong, S., \& Ellis, M. (2014) emphasized that it is important to ensure that student teachers are able to carry out specific linguistic tasks especially if English is the medium of instruction in school thus, pre-service and in-service teachers need to have proficiency in the language to be able to teach effectively. Educators need to be proficient in the language of instruction for they also help their students develop oral language skills both directly though linguistic interaction with them and indirectly by creating an environment, which is rich in learning stimuli (Mousena and Sidiropoulou, 2017).

\section{METHOD}

This study made use of the non-experimental quantitative research design that employed both the quantitative and qualitative methods in gathering the data on the pre-service teachers oral communication abilities using the researcher made questionnaire and validated through the focus group discussions. This was conducted among all the twenty-six student teachers who had their practice teaching in the University of San Carlos, College of Education. There were 16 student teachers who specialize in English and Filipino language, six Music, Arts, Physical Education and Health (MAPEH), three Religious Education (ReEd), and one English major. Their On-Campus practice teaching was done in USC Basic Education South Campus (laboratory school) and their Off-Campus was completed in Abellana National School (a public school in Cebu City).

During the students' practice teaching session class, students were asked to identify specific oral communication needs in their classroom teaching using the researcher-made survey questionnaire. They were asked to rate their own oral communication skills in relation to their pre-service teaching practice. A focus group discussion was conducted to validate the students' answers and solicit specific explanations on their classroom teaching practices. Classroom observations were used to compare the student-teachers' perceptions based on their student teaching performance particularly on how they deliver their lessons in class using English as their medium of instruction. 


\section{FINDINGS DISCUSSION}

This section presents the results of the oral communication skills needs among the preservice teachers based on their perceptions and validated during the researchers' classroom observations and focused group discussions.

\begin{tabular}{|l|l|l|}
\hline Oral Communication Ability & Perceived Needs & Rank \\
\hline Ability to formulate questions & 26 & 1 st \\
\hline Ability to answer questions & 19 & 5th \\
\hline Ability to communicate spontaneously & 20 & 4th \\
\hline Ability to pronounce words correctly & 21 & 3rd \\
\hline Ability to process students' answers & 22 & 2nd \\
\hline
\end{tabular}

Figure 1. Pre-service Teachers' Perception and Classroom Observation Results

The oral communication abilities needs expressed by the students teachers were: ability to formulate questions in English, ability to answer student's questions in English, ability to communicate spontaneously, ability to pronounce words correctly, and ability to process students' answers. Student teachers expressed that they encounter difficulty in fluency, pronunciation, processing students' answers in English and formulating higher order thinking skills (HOTS) questions. Student-teachers' experience during their practicum reflect the school and classroom complexity of place, ideology, knowledge, pedagogy and student-teacher assessment that lead them to question, modify, or abandon what they have learnt in their higher education initial teacher education courses in light of what often seems to be a different philosophy and practice (Russell, 2000; Sinclair, Munns, \& Woodward, 2005) as cited by Sinclair, 2007. Pre-service teachers oral communication ability during classroom discussions is still limited and they fall short of the oral communication skills expected of them as future teachers (Delfin, 2009). Richards (2010) in Low, E., Chong, S., \& Ellis, M. (2014) affirms the need for pre-service and in-service teachers need to have a level of English proficiency to be able to teach effectively.

Student teachers expressed their need in attending a special English class that specifically focus on developing their language and oral communication skills in English so they can improve their classroom teaching since English is the medium of instruction used in class. Emanuel (2005) affirms this in his study that oral communication subject/s or course should be as broad-based and exhaustive as possible. Furthermore, pre-service teachers also suggested that attending seminar and joining English club could also enhance their English language proficiency. It was found out that the pre-service teachers oral communication skills in English need to be enhanced to cope with the demands of the teaching profession. Likewise, it was noted that the need to have a special kind of English class for in-service teachers is very much needed to help them in their practice teaching since the language of instruction used in their classes is in English. Further, the kind of English they need for classroom communication is also very specific for classroom teaching and discussions. The findings serve as basis in designing a remedial class in English for Pre-Service Teachers.

\section{CONCLUSION AND RECOMMENDATIONS}

Based on the findings of the study, pre-service teachers expressed their limitations in using the English language as they present their lessons and communicate with their students during their classroom teaching. The analysis on the ability of student teachers in the use of English in the classroom is not enough to sustain them in their lesson presentations and class discussions and thus affect how they answer students' questions and how they ask questions and process students' answers in class during classroom interaction. In effect, they tend to do code-switching to emphasize certain points and even in giving examples and instructions. 
Thus, their oral communication ability in English needs to be improved in order to cope with the demands of the teaching and learning process. Furthermore, the pre-service teachers are aware of their limitations on their English oral communications skills and expect that they be provided with interactive class activities to improve their language skills.

Based on the conclusions, these are the recommendations:

1. Attending a special English class or a remedial class in English for Pre-Service Teachers can be used as an additional course or as an elective class for pre-service teachers to prepare them in their practice teaching.

2. Seminar on the art of questioning is necessary in order for them to formulate grammatical and higher order thinking skills questions during their classroom teaching demonstrations. This can be reinforced by having workshop sessions where students take turns asking and answering questions in English to practice their oral communication ability.

3. Creating an English club like Toastmasters Group or having English buddies can help students practice their language and oral communication skills and even improve their confidence in using the English language with peers. This can be done weekly or bimonthly where students discuss topics in English and share their views and ideas on topics related to English language teaching.

4. Curriculum analysis and revision must be done every after semester to validate if the content reflected matches with the expected competencies of the future teachers.

\section{Ethical Considerations and Data Management}

The researchers sought consent from the student-teachers during the interviews and focus group discussions by filling out the informed consent form. The data are kept confidential and stored in the Teacher Education Department.

\section{Availability of data and materials}

The data of this study are available at the Teacher Education Department of the University of San Carlos but restrictions apply to the availability of these data which are not publicly available. Ethical clearance had been obtained.

\section{ACKNOWLEDGEMENTS}

The authors acknowledge with gratitude the student teachers who took part in this academic undertaking as their useful feedback provided profound information on the topic identified.

\section{REFERENCES}

Bower, M. G., Moloney, R. A., Cavanagh, M. S., \& Sweller, N. (2013). Assessing Preservice Teachers' Presentation Capabilities: Contrasting the Modes of Communication with the Constructed Impression. Australian Journal of Teacher Education, 38(8).

Canale, M. \& Swain, M. (1980).Theoretical Bases of Communicative Approaches to Second Language Teaching and Testing. Retrieved from https://academic.oup.com/applij/article-abstract/I/1/1/181953

Celce-Murcia, M. (2008). Rethinking the role of communicative competence in language teaching. In E. A. Soler \& M. P. S. Jorda (Eds.), Intercultural language use and language learning. Springer Science+Business Media B.V. (pp. 41-58).

Castro Garcés, A. Y., \& López Olivera, S. F.(2014). Communication strategies used by preservice English teachers of different proficiency levels. Retrieved from http://dx.doi.org/10.19183/how.21.1.12. 
Chan, V. \& Kong, H. (2001). Determining Students' Language Needs in a Tertiary Setting. Retrieved from httts://www.researchgate.netpublication/265566434

Darling-Hammond, L (2006) Powerful Teacher Education, San Francisco, CA: Jossey-Bass.

Delfin, C.A.J. (2009). English Proficiency Levels of Student Teachers in Relation to their Student Teaching Performance. Unpublished Doctoral Dissertation, Cebu City, Philippines: University of San Carlos.

Denby, Neil ed. (2012). Training to Teach: A Guide for Students. London: SAGE Publications

Dunbar, N.E., Brooks, C.F. \& Kubicka-Miller, T. Innov High Educ (2006) 31: 115. https://doi.org/10.1007/s10755-006-9012-X

Fatih Kana (2015) Investigation of Pre-service Teachers' Communication SkillsThe International Journal of Educational Researchers

Freeman, D and Johnson, K (1998) Reconceptualising the knowledge base of language teacher education, TESOL Quarterly 32(3), 397-417.

Ganal, N.N. \& Andaya, O.F. (2015). Problems of Prospective Teachers of Philippine Normal University, North Luzon Campus During Practice Teaching. Asia Pacific Journal of Research Vo.1. Issue 28, June 2015

Jaca, C. A. (1999). English for Academic Purposes of Engineering Students in the University of San Carlos: Teaching Modules and Linguistic Skills. Unpublished Masters Thesis, Cebu City, Philippines: University of San Carlos.

Leung, C (2009) Second language teacher professionalism, in Burns, A and Richards, J (Eds) Second Language Teacher Education, Cambridge: Cambridge University Press, 49-58.

Lindsay Miller and Deborah Aldred (2000). Student Teachers' Perceptions About Communicative Language Teaching Methods. Singapore Regional Language Center Journal SEAMEO.

Low, E., Chong, S., \& Ellis, M. (2014). Teachers' English communication skills: Using IELTS to measure competence of graduates from a Singaporean teacher education program. Retrieved from http://dx.doi.org/10.14221/ajte.2014v39n10.5

McCarthy, M.R. and R. Carter (2001). Ten Criteria for a Spoken Grammar in E. Hinkel and S. Fotos (eds). New Perspectives on Grammar Teaching in Second Language Classrooms. Mahwah, NJ:Lawrence Erlbaum Associates.

Mousena E. and T. Sidiropoulou (2017). Oral Communication Skills and Pedagogy. New Pedagogical Challenges in the $21^{\text {st }}$ Century-Contributions of Research in Education Retrived from https://www.intechopen.com/books/new-pedagogical-challenges-inthe-21st-century-contributions-of-research-in-education/oral-communication-skillsand-pedagogy doi:10.5772/intechopen.70831

Nadia Mayahi and FatemehMayahi (2014), Procedia - Social and Behavioral Sciences Retrived from https://do.org/10.1016/j.sbspro.2014.03.524

Rahman, Md. (2010). Teaching Oral Communication Skills: A Task-based Approach. English for Specific Purposes World. 9.

Richard Emanuel (2005) The Case for Fundamentals of Oral Communication, Community College Journal of Research and Practice, 29:2, 153162, DOI: 10.1080/10668920490891638

Richards, J. C. (2010). Competence and performance in language teaching. Retrieved from http://dx.doi.org/10.1177/0033688210372953

Sinclair, Catherine (2007). Professional Preparation Standards for the Practicum.Standards in Education . USA: Information Age Publishing.

Sng Bee Bee, China (2012). Humanizing Language Teaching. Retrieved from http://www.hltmag.co.uk/feb12/mart.htm 
Stephen Hunt, Cheri Simonds \& Pamela Cooper (2002) Communication and Teacher Education: Exploring a Communication Course for All Teachers. Retrieved from DOI: $10.1080 / 03634520216497$

Vassallo, Odette. (2005). Teacher Talk and Learner Involvement in EFL Classroom Retrieved from www.academypublication.com/issues/past/tpls/vol02/11/05.pdf 